\title{
Bandung City Image as A Halal Tourism Destination
}

\author{
Vanessa Gaffar ${ }^{1, *}$ Yeni Yuniawati ${ }^{2}$ Lili Adi Wibowo ${ }^{3}$, Oce Ridwanudin ${ }^{4}$ \\ ${ }^{1}$ Universitas Pendidikan Indonesia \\ ${ }^{2}$ Universitas Pendidikan Indonesia \\ ${ }^{3}$ Universitas Pendidikan Indonesia \\ ${ }^{4}$ Universitas Pendidikan Indonesia \\ ${ }^{*}$ Corresponding author. Email: vanessa@upi.edu
}

\begin{abstract}
This research aimed to analyze tourist perception towards image of Bandung City as one of halal tourism destinations in Indonesia. It measured some factors including food, accommodation, attraction and local people. The research method used was quantitative research design. In data collection, the research used questioners. The subjects of the research covered 200 tourists who travelled to Bandung. The result of the research showed that the majority of the tourists perceived halal label to be important so it is their priority to dine in, in a restaurant with halal certificate. Most of the accommodations and attractions had already provided an appropriate worship place although the worship equipment was still limited and sometime it was poorly maintained. Most tourists were expected to get a clear prayer notification on the site and a clear signage to the worship place. They felt convenience to interact with Muslim local people without feeling harsh. It is important for the government, especially office of culture and tourism to educate people on what the true definition of halal tourism is since there were still misconception perceptions among tourists and local people themselves.
\end{abstract}

Keywords: city image, halal tourism, tourism destination.

\section{INTRODUCTION}

Tourism management examines in depth research that enhances readers' knowledge and expertise in specific topics in five general areas of tourism management, namely scanning and idea generation, planning, implementation, activity and impact assessment and administration [1]. According to reference [2] was tourism management involves the management of many activities such as studying tourist destinations, planning trips, making travel arrangements, and providing accommodation. Tourism management also involves marketing efforts to attract tourists to go to specific destinations. Many scholars argue that the market for tourism has become increasingly fragmented into various parts, each with its own customers, desired locations, forms of organization and associated impacts.

There are many types of tourism according to reference [2] such as mass tourism, alternative tourism, business tourism, pleasure tourism, nature tourism, cultural tourism, social tourism, recreational tourism, active tourism, sports tourism, religious tourism, health or medical tourism, and adventure tourism. There are several types of tourism management based on the study.

One of them is religious tourism. Religious tourism is one of the oldest types of tourism [3,4]. It often involves in visiting the holy cities of the faith in certain followers whose trips to these sites take place on the commemoration of events important to their religion (tourists) [5]. 
Reference [6] was stated that one of the subtypes of religious tourism is halal tourism. It refers to the provision of tourism products and services that meet the needs of Muslim tourists [7]. The concept of halal is not only related to food and drink (as people expect or think), but includes all the aspects of Muslim life [8]. It means that the concept of halal includes all products that are in accordance with Islamic sharia. Thus, Halal tourism is not only done at locations or places with a majority of Muslims, but the services and products provided in the concept of halal tourism are also designed for non-Muslim tourists. In addition, the purpose of halal tourism does not have to be religious, but it can be as motivation in tourism in general [9].

As we all know that the tourism industry is one of the largest economic sources in the world. According to the World travel \& tourism council (WTTC) in 2018 the tourism industry experienced growth of $3.9 \%$. It is compared to the global economy which is $3.2 \%$ [10]. Halal tourism is one of the fastest growing segments in the world tourism industry. It has tremendous potential in the growth and development of halal tourism [11]. This is reinforced by the global Muslim travel index (GMTI) which says that the halal tourism market will become one of the fastest growing segments of the global travel industry. Mastercard Crescent Rating ranks Indonesia as the best halal destination in the world 2019 by GMTI which consist of outperforming 130 destinations from all over the world. It means that Indonesia becomes the first place with a score of 78, alongside Malaysia, which are both in the top ranking [12].

Since 2015, the Indonesian Ministry of Tourism has been seriously in developing halal tourism. To realize it, Indonesia has made Indonesia Muslim Travel Index (IMTI) with reference to the GMTI global standard. GMTI analyzes based on 4 strategic assessment criteria that cover in access, communication, environment, and services. By doing so, Indonesia continues to improve the performance of 10 leading halal destinations at IMTI 2018, in which has a huge influence that will prove Indonesia to be the best halal destination in the world in 2019. In addition, the Indonesian Ministry of Tourism takes the step to continue in developing and strengthening the potency of halal tourism in 2019 involved six districts and cities to become of top ten in leading the halal tourist destination in 2018.

Bandung is one of the cities that have become a leading halal destination to strengthen halal tourism in Indonesia. Since 2018, the municipality of Bandung has started to develop halal tourism. The Head of the Bandung City Culture and Tourism Office Kenny Kaniasari is optimistic that the tourist will increase to visit Bandung especially the tourists who come from Malaysia, Singapore and the Middle East to Bandung City will increase [13].
Halal tourism is part of tourism management. it is a tour with tourism services and facilities for Muslim tourists that can also be enjoyed by non-Muslim tourists. There are there characteristics of Muslim tourist. Those characteristics consist of 1) the existence of adequate facilities and worship services, 2) a friendly place to stay for Muslim tourist, 3) the halal food and beverages with halal guarantees through the halal certification [14] Thus, tourist destinations for halal tourism should cover in natural, cultural, and artificial tourism that are equipped with facilities or infrastructure for worship, such as the presence of mosques or prayer rooms around the place tourism.

There are some definitions of halal tourism. The Organization of the Islamic Conference (OIC) provides a definition of halal tourism, the terminology used by the OIC is Islamic Tourism. It is based on the Qur'an article 29:20 which encourages humans to travel on earth to take lessons from Allah's creation and take blessings. It can be said that the Islamic Tourism is defined as a tour that is intended to provide tourist services and facilities for Muslin tourists according to Islamic principles. There are several terms used in Islamic Tourism such as Halal Tourism, Sharia Tourism, and Muslim Friendly Tourism [14]. In other hand, GMTI 2016 as an institution that focuses on developing world halal tourism explains that halal tourism is tourism that is accordance with Islamic principles. They further said that the halal tourism aims to provide the facilities and services that are friendly to Muslim tourists. Then, the halal tourism in Indonesia should be a line with GMTI.

Another definition of halal tourism comes from reference [4] was stated that halal tourism is travel made for recreational, leisure and social purposes, although the motivation to travel is not necessarily spiritual. Meanwhile reference [7] was stated that halal tourism is the provision of tourism products and services that meet the needs of Muslim tourists according to Islamic teachings. In addition, reference [8] was states that halal tourism are permitted or permitted according to Islamic teachings while Halbase in reference [8] halal tourism offers the tour packages and specific destinations to meet Muslim considerations and needs. Then, it can be concluded that halal tourism refers to service and facilities which are provided by Islamic principles.

The previous study on halal tourism had been carried out by reference [7] was focused on the process of increasing the awareness in developing and indentifying the specific needs in halal tourism. Meanwhile, the study that was also conducted by reference [15] concerned about the current trends of halal tourism in Asia. Another, previous study came from [16]. He highlighted on the halal food and halal certification. In addition, the study that was carried out 
by [17] explained about the industrial halal tourism in Indonesia.

Based the previous study above, many researchers just focus on the halal tourism, but it is only a few studies that discuss about the image of a halal tourism destination specifically. Therefore, the researcher inspires to conduct this research. Furthermore, this research aims to obtain about the findings toward Bandung as halal tourism based on the tourists' perception.

\section{METHODS}

This research analyzed the tourist perception of Bandung City as a halal tourism destination. The variable of the research was the halal tourism where consisted of food and beverage, accommodation, attraction and local people [14]. The sample of the study covered 200 tourists who visited Bandung. Besides, the sampling technique used was incidental sampling.

The analysis method used was frequency analysis with mathematical distribution to obtain the number of responses with different values from one variable and two variables to reveal the amount in the presentation [20] and the calculation of the ideal score. table 1 showed the measurement of variable, namely halal tourism.

Table 1. Measurement of Variable

\begin{tabular}{|c|c|}
\hline Variable/Dimension & Measurement \\
\hline \multicolumn{2}{|l|}{ Halal Tourism } \\
\hline \multirow[t]{4}{*}{$\begin{array}{l}\text { Food and Beverage } \\
\left(\mathrm{X}_{1}\right)\end{array}$} & $\begin{array}{l}\text { The searching level of information by } \\
\text { tourists toward halal food / places to eat } \\
\text { in Bandung }\end{array}$ \\
\hline & $\begin{array}{l}\text { The importance level of the halal label } \\
\text { on food / places to eat }\end{array}$ \\
\hline & $\begin{array}{l}\text { The credible level of food / places to eat } \\
\text { without a halal label }\end{array}$ \\
\hline & $\begin{array}{l}\text { The priority level in buying food or } \\
\text { choosing a place to eat in labelled halal }\end{array}$ \\
\hline \multirow[t]{7}{*}{ Accommodation $\left(\mathrm{X}_{2}\right)$} & $\begin{array}{l}\text { The priority level of staying at sharia } \\
\text { accommodation in Bandung City }\end{array}$ \\
\hline & $\begin{array}{l}\text { The availability of places of worship in } \\
\text { accommodation in Bandung City }\end{array}$ \\
\hline & $\begin{array}{l}\text { The availability of worship equipments } \\
\text { in accommodation (qibla direction, Al } \\
\text { Quran, ablution place) }\end{array}$ \\
\hline & $\begin{array}{l}\text { The level of satisfaction with the } \\
\text { worship place and tools of worship } \\
\text { provided by the accommodation }\end{array}$ \\
\hline & $\begin{array}{l}\text { The comfort level of staying at } \\
\text { accommodation that provides liquor and } \\
\text { entertainment venues (pubs, discos) }\end{array}$ \\
\hline & $\begin{array}{l}\text { The desire to have many Islamic } \\
\text { accommodation options }\end{array}$ \\
\hline & $\begin{array}{l}\text { The level of desire to stay in } \\
\text { accommodation that separates facilities } \\
\text { based on gender (swimming pool, gym, } \\
\text { etc.) }\end{array}$ \\
\hline \multirow[t]{2}{*}{ Attraction $\left(\mathrm{X}_{3}\right)$} & $\begin{array}{l}\text { The priority level to look for halal } \\
\text { tourist attractions }\end{array}$ \\
\hline & $\begin{array}{l}\text { The level of availability of places of } \\
\text { worship in tourist places (malls, tourist } \\
\text { attractions, etc.) }\end{array}$ \\
\hline
\end{tabular}

\begin{tabular}{|c|c|}
\hline & $\begin{array}{l}\text { The level of satisfaction with the } \\
\text { cleanliness of places of worship in } \\
\text { tourist destinations (cleanliness of } \\
\text { places, places of worship, places of } \\
\text { ablution) }\end{array}$ \\
\hline & $\begin{array}{l}\text { The importance level of tourist } \\
\text { attractions in providing the prayer time } \\
\text { to visitors }\end{array}$ \\
\hline & $\begin{array}{l}\text { The clarity level of markers of places } \\
\text { of worship in tourist areas and public } \\
\text { spaces }\end{array}$ \\
\hline & $\begin{array}{l}\text { The interest level of tourist attractions } \\
\text { that separates men and women (if any) }\end{array}$ \\
\hline \multirow[t]{4}{*}{ Local Residents $\left(\mathrm{X}_{4}\right)$} & $\begin{array}{l}\text { The comfort level in the middle of the } \\
\text { local residents of Bandung City }\end{array}$ \\
\hline & $\begin{array}{l}\text { The level of appropriateness of the local } \\
\text { people in dressing up }\end{array}$ \\
\hline & $\begin{array}{l}\text { The level of politeness of the local } \\
\text { population in interacting with the } \\
\text { opposite sex }\end{array}$ \\
\hline & $\begin{array}{l}\text { The level of obedience of local } \\
\text { residents to religious teachings }\end{array}$ \\
\hline
\end{tabular}

\section{RESULT AND DISCUSSION}

The data covered demography aspects and experiences of respondents. Table 1 showed that most of the respondents were female $(54.5 \%)$ while male were $45.4 \%$. The majority age was $18-25$ years old $(78 \%)$ and made the highest proportion of education background fell into student $(60.5 \%)$. For monthly income, majority of respondents earn <Rp 2.000 .000 (48.5\%). Tourists came from different parts of the country that counts for $57 \%$ with the purpose of visit mostly for holiday $(58.5 \%)$. Most of them stay between 1-3 days in Bandung. It can be seen in table 2 below.

Table 2. Adjust R Square

\begin{tabular}{|c|c|c|c|}
\hline & Catergory & Frequency & Percent \\
\hline \multirow[t]{2}{*}{ Gender } & Male & 91 & 45.4 \\
\hline & Female & 101 & 54.5 \\
\hline \multirow[t]{4}{*}{ Age } & $18-25$ yo & 156 & 78 \\
\hline & $26-30$ yo & 32 & 16 \\
\hline & $31-35$ yo & 7 & 3.5 \\
\hline & $>36$ yo & 5 & $2 .<$ \\
\hline \multirow[t]{5}{*}{ Occupation } & Student & 121 & 60.5 \\
\hline & Entrepreneur & 34 & 17 \\
\hline & Employee & 22 & 11 \\
\hline & $\begin{array}{l}\text { Government } \\
\text { Officer }\end{array}$ & 12 & 6 \\
\hline & Others & 10 & 5 \\
\hline \multirow[t]{3}{*}{ Monthly income } & $<2.000 .000$ & 97 & 48.5 \\
\hline & $\begin{array}{l}2.000 .001- \\
4.000 .000\end{array}$ & 66 & 33 \\
\hline & $\begin{array}{l}4.000 .001- \\
5.000 .000\end{array}$ & 23 & 11.5 \\
\hline י & $>5.000 .000$ & 14 & 7 \\
\hline \multirow[t]{6}{*}{ Home Town } & Jakarta & 23 & 11.5 \\
\hline & Bogor & 31 & 15.5 \\
\hline & Bekasi & 13 & 6.5 \\
\hline & Depok & 6 & 3 \\
\hline & Tangerang & 13 & 6.5 \\
\hline & Others & 114 & 57 \\
\hline \multirow[t]{4}{*}{ Purpose of Visit } & Holiday & 117 & 58.5 \\
\hline & Business & 22 & 11 \\
\hline & Study & 55 & 27.5 \\
\hline & Others & 6 & 3 \\
\hline
\end{tabular}




\begin{tabular}{|l|l|l|l|}
\hline Length of Stay & $1-3$ days & 95 & 47,5 \\
\hline & $4-7$ days & 54 & 27 \\
\hline & $>7$ days & 51 & 25.5 \\
\hline \multicolumn{4}{|c|}{ Source: Data processing, 2019}
\end{tabular}

Based on the data, the analysis of tourist perception in halal tourism which includes food and beverage, accommodation, attraction and local people can be explained form table 3 below in the average score of the variable with its each dimension.

Table 3. Tourist Perception on Halal Tourism in Bandung City

\begin{tabular}{|l|l|l|l|l|l|}
\hline No & \multicolumn{1}{|c|}{ Dimension } & Item & $\begin{array}{c}\text { Total } \\
\text { Score }\end{array}$ & $\begin{array}{c}\text { Average } \\
\text { Score }\end{array}$ & \% \\
\hline 1. & $\begin{array}{l}\text { Food and } \\
\text { Beverage }\end{array}$ & 4 & 3223 & 805.75 & 29 \\
\hline 2. & Accommodation & 7 & 4814 & 687.71 & 31 \\
\hline 3. & Attraction & 6 & 4396 & 732.67 & 28 \\
\hline 4 & Local Residents & 4 & 3010 & 752.50 & 20 \\
\hline & Total & 12 & 15443 & 2978.6 & 100 \\
\hline
\end{tabular}

Source: Data processing, 2019

From table 3 it can be seen that the dimension of halal tourism that had the highest score was food and beverage with an average score of 805.75 . It proved that food and beverage in Bandung City had been trusted to be halal by tourists. As it is known that $90 \%$ of the original population of Bandung City is Muslim. The dimension of halal tourism with the lowest score is accommodation with an average score of 687.71. It is caused that the Islamic hotel is Bandung is still few.

Based on the data, the number average score of halal tourism in Bandung City was 15443 and 2978.6. The calculations are carried out to find the maximum index value and minimum index value, which can be calculated to get the variable level and interval distance in making the percentage score and setting on the continuum line as follows fig. 1.

Maximum Index Value:

Highest score x Number of Questions x Number of Respondents

$=5 \times 21 \times 200=21000$

Minimum Index Value:

Lowest Score x Number of Questions x Number of Respondents

$=1 \times 21 \times 200=4200$

Score Level:

Maximum Index Value - Minimum Index Value

$=21000-4200=16800$

Length of Interval Class:

Score Level / Number of Interval Classes

$=16800 / 5=3360$
420 756

10920

14280

1764

21000

Figure 1. The continuum line of Bandung City image as Halal Tourism Destination

It can be concluded that halal tourism in Bandung City was in the good category indicated by a total score of 15443. The good category indicated that the city of Bandung was worthy of being called a halal tourist destination. It means that the city of Bandung is one of the halal tourism destinations that are considered capable of implementing the concept of halal tourism well through the dimensions of accommodation, food and beverage, accommodation, attractions and local residents. It provided sufficient benefits for Bandung City, but it would be better if it could be improved through the attributes that were considered to be not good enough at the moment shown as table 4 .

Table 4. Items on Halal Tourism in Bandung City

\begin{tabular}{|c|c|c|}
\hline No & Items & Score \\
\hline & $\begin{array}{l}\text { Searching for halal information on halal food } \\
\text { / places to eat during a visit to Bandung }\end{array}$ & 789 \\
\hline & $\begin{array}{l}\text { The importance of labelled food . places to } \\
\text { eat }\end{array}$ & 933 \\
\hline & $\begin{array}{l}\text { Trusting in food / places to eat even though } \\
\text { there is no halal label }\end{array}$ & 669 \\
\hline & $\begin{array}{l}\text { Priority to buy food . places to eat labelled } \\
\text { halal }\end{array}$ & 832 \\
\hline & $\begin{array}{lc} & \text { Total Score } \\
\end{array}$ & 3233 \\
\hline \multicolumn{3}{|c|}{ Accomodation } \\
\hline & $\begin{array}{l}\text { Priority to stay in sharia accommodation in } \\
\text { Bandung City }\end{array}$ & 595 \\
\hline & $\begin{array}{l}\text { Availability of places of worshing in } \\
\text { accommodation (qibla direction, Al Auran, } \\
\text { ablution place) }\end{array}$ & 732 \\
\hline & $\begin{array}{l}\text { Satisfaction with the worship place and tools } \\
\text { of worship provided by the accommodation }\end{array}$ & 673 \\
\hline & $\begin{array}{l}\text { The comfort of staying even though the } \\
\text { accommodation is provided with liquor and } \\
\text { enteratiment venues (pubs, discos) }\end{array}$ & 594 \\
\hline & $\begin{array}{l}\text { The desire to have many sharia } \\
\text { accommodation options in Bandung City }\end{array}$ & 752 \\
\hline & $\begin{array}{l}\text { The desire to stay in accommodation that } \\
\text { separates facilities based on gender } \\
\text { (swimming poolm gym, etc.) }\end{array}$ & 660 \\
\hline & Total Score & 4814 \\
\hline \multicolumn{3}{|c|}{ Attraction } \\
\hline & $\begin{array}{l}\begin{array}{l}\text { The priority to look for halal tourist } \\
\text { attractions }\end{array} \\
\end{array}$ & 718 \\
\hline & $\begin{array}{l}\text { The satisfy with the clean places of worship } \\
\text { in tourist destinations (cleanliness of place, } \\
\text { places of worship, places of ablution) }\end{array}$ & 697 \\
\hline & $\begin{array}{l}\text { The importance of tourist attractions } \\
\text { informing prayer times to visitors }\end{array}$ & 810 \\
\hline & $\begin{array}{l}\text { The clarity of signage worship place in } \\
\text { tourist areas and public spaces }\end{array}$ & 763 \\
\hline & $\begin{array}{l}\text { Interest in tourist attractions that separate } \\
\text { men and women (if any) }\end{array}$ & 598 \\
\hline & Total Score & 4396 \\
\hline \multicolumn{3}{|c|}{ Local Residents } \\
\hline
\end{tabular}




\begin{tabular}{|l|l|l|}
\hline & $\begin{array}{l}\text { The comfort of being in the middle of the } \\
\text { local residents when in Bandung }\end{array}$ & 840 \\
\hline & $\begin{array}{l}\text { The appropriateness of the local residents in } \\
\text { dressing up }\end{array}$ & 727 \\
\hline $\begin{array}{l}\text { The courtesy of local residents in interacting } \\
\text { with the opposite sex }\end{array}$ & 733 \\
\hline $\begin{array}{l}\text { The obedience of local residents to religious } \\
\text { teachings }\end{array}$ & 710 \\
\hline \multicolumn{2}{|c|}{ Total Score } & 3010 \\
\hline
\end{tabular}

Source: Data processing, 2019

Table 4 above shows the results of tourists' responses to halal tourism in Bandung City. In the food and beverage dimension, the highest score was the second item, the importance of halal labels on food / places to eat, with a score of 933. In the accommodation dimension, the highest score was the second item while the availability of places of worship in accommodations Bandung City was in score of 808 . Besides, in the attraction dimension, the one who got the highest score the highest was the second and fourth items, availability of places of worship in tourist places (malls, tourist attractions, etc.) and The importance of tourist attractions in informing prayer times to visitors, with a score both 810 . In other hand, the local residents, the one that got the highest score was the first item, the comfort of being in the middle of the local residents when in Bandung, with a score of 840 .

The results showed that tourists really paid attention to halal labels on food or places to eat so that business people needed to pay attention to the labelled halal on the products offered. Currently, the labelled halal food or places to eat in Bandung is practiced, but there are still many products that do not have labelled halal. Tourists tend to be reluctant to choose foods or places to eat that do not have a halal label. Business managers need to pay attention to the procurement of halal labels on food or places to eat, because this will benefit both business people and tourists.

In terms of accommodation in Bandung City, the majority have provided proper places of worship. The facilities that were provided worship place are currently adequate. Tourists feel inconvenience when staying in accommodation that provides liquor and entertainment venues such as pubs and discos.

The availability of worship place at tourist attractions such as malls and tourist attractions is good. Currently, the majority of tourist attractions in Bandung have provided adequate worship place. This shows that there are still few tourists who have an interest in tourist attractions that separate men and women. The results also show that the local residents of Bandung City give a comfortable impression through friendly behavior towards tourists. However, even though $90 \%$ of the local population in Bandung is Muslim, there are still many people who have not followed the teachings of Islam properly

\section{CONCLUSION}

Based on the result of the research, it can be seen that tourists support the image of Bandung City as halal tourism. Generally, tourists' responses to halal tourism in Bandung consist of food and beverages, accommodation, attractions and local residents. The factors in halal tourism in Bandung that got the highest score were food and beverage which were measured by the level of halal food and beverage in the city of Bandung. The factor in halal tourism with the lowest value was indicated through the accommodation aspect. It means that Bandung is still not accordance with the halal value. Overall, the tourists have a good perception of the city of Bandung as a halal tourist destination. It can be seen from the tourists who paid attention to halal aspect in their tourism activities in Bandung city. Tourists from the city of Bandung can experience the good halal tourism in this city. Thus, it is proven to be important for tourists in providing halal tourism. Furthermore, the management needs to maintain and increase halal tourism which consists of food and beverages, accommodation, attractions and local residents in the city of Bandung.

\section{ACKNOWLEDGMENT}

We thank to Department of Culture and Tourism of Bandung City Indonesia that has supported the reseacrhers this work.

\section{REFERENCES}

[1] R. Buckley, Adventure tourism management, 2010.

[2] Wall and Mathieson, Tourism management, tutorials point (I) Pvt. Ltd," 2016.

[3] G. Rinschede, Forms of religious, 19, 51-67, 1992

[4] K. Rundquist, Leap of faith, Religious Tourism Report, ASTA Network, pp. 40-43, . 2010.

[5] B. Kartal, M. Tepeci and H. Atl1, "Examining the religious tourism potential of manisa , turkey with a marketing perspective," 2015, doi: https://doi.org/10.1108/TR-09-2013-0048

[6] M. Bon, M. Hussain, J. C. Henderson, A. Shakeela, L. Ruhanen, and N. Breakey, "Tourism in the muslim world article information," 2010, doi: https://doi.org/10.1108/S20421443(2010)0000002007

[7] A. Mohsin, N. Ramli, and B. Abdulaziz, "Halal tourism : emerging opportunities, "19,2016, 20152017.

[8] H. El-gohary, "Halal tourism, is it really Halal ? TMP," 2015, "Hoi: https://doi.org/10.1016/j.tmp.2015.12.013

[9] M. Battour and M. N. Ismail, "Halal tourism: concepts , practises, challenges and future.," TMP, 
19, $\quad 150-154, \quad 2016, \quad$ doi: https://doi.org/10.1016/j.tmp.2015.12.008

[10] September 25, 2019. [Online]. Available: https://wttc.org/

[11]A. Vargas-sánchez and M. Moral-moral, "Halal tourism: state of the art," 2018, doi: https://doi.org/10.1108/TR-01-2018-0015

[12] September 25 2019. [Online]. Available : http://kemenpar.go.id/

[13] September 25, 2019. [Online]. Available : https://ayobandung.com/

[14] A. R. Subarkah, "Diplomasi pariwisata halal nusa tenggara barat," Intermestic: J. of International Studies, Volume 2, No. 2, Mei 2018(2), 188-203, 2018.

[15] Organisasi Kerjasama Islam. Strategic roadmap for development of islamic tourism in oic member countries. Ankara-turkey: organisation of islamic cooperation: statistical, economic and social research, and training center for islamic countries, . 2017.

[16] Global Muslim Travel Index. Global muslim travel index report 2016 [Online]. Available: Singapore: Crescent Rating, 2016

[17]Z. Samori, N. Za and M. Mahyuddin, "Current trends on halal tourism: cases on selected asian countries," 2015, doi: https://doi.org/10.1016/j.tmp.2015.12.011

[18] J. C. Henderson, Halal food, certification and halal tourism: insights from malaysia and singapore. Tourism management perspectives," 19, 160-164, 2016.

[19] A. Jaelani, "Halal tourism industry in indonesia: potential and prospects. international review of management and marketing," 7(3), 2017.

[20]N. K. Malhotra, Marketing research an applied orientation, New Jersey: Pearson, . 2010 